\title{
Toxicity Term Code
}

National Cancer Institute

\section{Source}

National Cancer Institute. Toxicity Term Code. NCl Thesaurus. Code C93696.

A coded value specifying the degree to which a substance is poisonous. 